\title{
Metsulfuron-methyl Herbicide on Dehydrogenase and Acid Phosphatase Enzyme Activity on Three Different Soils
}

\author{
Shaon Kumar Das ${ }^{1^{*}}$, Irani Mukherjee ${ }^{2}$ and Suvo Kumar Das ${ }^{3}$ \\ ${ }^{1}$ ICAR-National Organic Farming Research Institute, Tadong, Gangtok, Sikkim $(737$ 102), India \\ ${ }^{2}$ Division of Agricultural Chemicals, IARI, New Delhi (110 012), India \\ ${ }^{3}$ ADA, Govt. of West Bengal, Darjeeling, West Bengal (734 221), India
}

\section{Corresponding Author}

Shaon Kumar Das

e-mail: shaon.iari@gmail.com

\author{
Article History \\ Manuscript No. AR1712 \\ Received in $19^{\text {th }}$ October, 2016 \\ Received in revised form $13^{\text {th }}$ March, 2017 \\ Accepted in final form $5^{\text {th }}$ April, 2017
}

\begin{abstract}
An experiment was conducted during the year 2012-13 to investigate the effects of metsulfuron-methyl herbicide on dehydrogenase and acid phosphatase activity on three diverse soils at two doses ( 4 and $6 \mathrm{~g}$ a.i. ha- ${ }^{-1}$ ). Different soils exhibited different rates of recovery of soil dehydrogenase and acid phosphatase activity in a period of 15 days after application. Initial dehydrogenase value $1.26,1.17$ and 1.11 reached to final 1.28, 1.14 and 1.03 at lower dose; initial dehydrogenase value 1.26, 1.17 and 1.11 reached to final $1.24,1.09$ and 0.97 at higher, respectively for entisol, mollisol and inceptisol. Similarly, Initial acid phosphate value 1.30, 1.28 and 1.31 reached to final 1.26, 1.28 and 1.26 at lower dose; initial acid phosphate value 1.30, 1.28 and 1.31 reached to final 1.26, 1.22 and 1.25 at higher, respectively for entisol, mollisol and inceptisol. In this study metsulfuron-methyl exerted an initial adverse effect on both enzyme activity but dehydrogenase activity restored in due course of time in each soil. To prevent adverse effects especially in Inceptisol a higher recommended dose of $6 \mathrm{~g}$ a.i. ha ${ }^{-1}$ should be avoided. Recovery was faster in all the three types of soil at the lower dose. Lower recommended dose of $4 \mathrm{~g}$ a.i. ha-1 of metsulfuron-methyl would not significantly affect Entisol and Mollisol while in Inceptisol the recovery process was slower and can be accelerated by the addition of organic matter to the soil. At a higher dose of $6 \mathrm{~g}$ a.i. ha ${ }^{-1}$, the dehydrogenase activity recovery rate in all the soils types was slow.
\end{abstract}

Keywords: Enzymatic activity, entisol, inceptisol, mollisol, metsulfuron-methyl

\section{Introduction}

Pesticides undergo different dissipation processes in soil like microbial degradation, chemical hydrolysis, photolysis, volatilization, leaching and surface runoff (Das and Mukherjee, 2011). The contribution made by each of these dissipation processes towards the overall dissipation depends upon the nature of soil, pesticides and other environmental factor (Das and Mukherjee, 2012). Hence, it is important to avoid serious injury to the soil microflora, whose functions are vital in maintaining the soil fertility (Das and Mukherjee, 2014). Metsulfuron-methyl is a residual sulfonylurea herbicide used as a selective pre and post emergence for control of broadleaf weeds and some annual grasses. It is a systemic compound with foliar and soil activity and works rapidly after it is taken up by the plant. Its mode of action is by inhibiting cell division in shoots and roots of the plant, and it is biologically active at low dose. Soil dehydrogenase activity varies significantly with type and concentration of pesticides ${ }^{1}$. Inhibition of dehydrogenase by quinalphos and stimulation of dehydrogenase by chlorpyrifos has been reported by (Menon et al., 2005; Klose et al., 2006) reported that soil fumigation reduced dehydrogenase by $35 \%$ over a period of 90 days. Metalaxyl application initially increased and then decreased dehydrogenase in fungicide treated soil (Sukul, 2006). Singh and Kumar (2008) revealed that acetamiprid increased dehydrogenase upto $22 \%$ after the first application. Soils with different physicochemical properties are likely to have different soil microbial populations in terms of their activity, number and composition. Hence, each soil type will respond differently to the addition of any potentially toxic compound. Any factor that affects soil microbial population dynamics will alter soil enzyme activity (Das and Mukherjee, 2012).

Among soil enzymatic activities, dehydrogenase and phosphatase are the most commonly measured activities in soils and therefore proposed by many authors as potential indicators of soil state (Floch et al., 2011). There is also evidence that soil enzymes may provide valuable general information on transformation of pesticides in soils (Hussain et 
al., 2009). The majority of herbicides are either neutral toward this activity or they inhibit it (Jastrzebska, 2011). Herbicides, except butachlor (Xia et al., 2011), have a repressive effect on dehydrogenase activity, whatever conditions of application, including dose and soil pH (Sebiomo et al., 2012).

Though several studies have documented the effects of various herbicides application on soil microbial and enzyme activities (Goyal et al., 1993; Dinesh et al., 2000) no information is available on the role of metsulfuron-methyl herbicides soil enzyme activity under the conditions of North-western Indian Himalayas. Hence, in this study three physico-chemically different soils were used to assess the effect of metsulfuronmethyl herbicides at two different doses used in agriculture by conducting dehydrogenase and acid phosphatase activity test during 2013-2013 at ICAR-VPKAS, Almora, Uttarakhand.

\section{Materials and Methods}

The soils used in this experiment were entisol, mollisol and inceptisol order varying in physico-chemical properties. The experiment was conducted during the year 2012-13 at the experimental farm of Vivekananda Institute of Hill Agriculture, located in the Indian Himalayan region at Hawalbagh (29.36' $\mathrm{N}$ and $79^{\circ} 40^{\prime} \mathrm{E}$ with $1250 \mathrm{~m}$ amsl), in the state of Uttarakhand, India. Commercial grade metsulfuron-methyl was used in this experiment at two different application rates (4 and $6 \mathrm{~g}$ a.i. $\left.\mathrm{ha}^{-1}\right)$. Soil samples were collected in polythene bags, air dried in shade, ground, sieved through a $2 \mathrm{~mm}$ sieve and stored at room temperature. The soils belonged to Entisol, Mollisol and Inceptisol. All the soils belonging to three different orders were maintained at field capacity and incubated at $30 \pm 1{ }^{\circ} \mathrm{C}$ for a period of 15 days for revival of inherent soil microbial activity. Commercial formulation of the herbicide metsulfuron-methyl 20\% WP was added to each soil at 4 and 6 g a.i. ha-1 ${ }^{-1}$ Different physico-chemical properties were analysed with standard method (Jackson, 1967). Organic carbon measured by using the Walkley and Black method (1965), clay, sand and silt measured by employing the Bouyoucos hygrometer (Bouyoucos and Cook, 1967). The electrical conductivity was measured using conductivity meter. Soil $\mathrm{pH}$ (1:2.5), CEC [by $1 \mathrm{M} \mathrm{NH}_{4} \mathrm{OAc}(\mathrm{pH} 7)$ extraction], Olsen $\mathrm{P}$ (by $0.5 \mathrm{M} \mathrm{NaHCO}_{3}$ extraction), sulfate [by $0.04 \mathrm{M} \mathrm{Ca}\left(\mathrm{H}_{2} \mathrm{PO}_{4}\right)_{2}$ extraction], were measured according to Black (1965). Acid oxalate-extractable Fe and aluminum ( $\mathrm{Al})$, and exchangeable potassium (K), calcium (Ca), magnesium ( $\mathrm{Mg}$ ), and sodium $(\mathrm{Na})$ were determined for the initial soil samples by the standard methods of Blakemore et al. (1987). The properties of the collected soils from three different orders are given in Table 1. The lower dose (4 g a.i.) and higher dose ( $6 \mathrm{~g}$ a.i.) has been mentioned as LD and HD.

Soil was fortified at two level viz., $4 \mathrm{~g}$ a.i. and $6 \mathrm{~g}$ a.i. with the herbicide having three replications for each level of fortification. $10 \mathrm{~g}$ of soil was transferred in beakers and period of exposure was 15 days. Beakers in triplicate were withdrawn at $0,1,3,5,7,10$ and 15 days interval along with control sample. Soil dehydrogenase activity in triplicates
Table 1: Physico-chemical properties of three different soil types

\begin{tabular}{|c|c|c|c|}
\hline \multirow{2}{*}{$\begin{array}{l}\text { Physico-chemical } \\
\text { properties }\end{array}$} & \multicolumn{3}{|c|}{ Soil order } \\
\hline & Entisol & Mollisol & Inceptisol \\
\hline $\mathrm{pH}$ & 6.4 & 6.9 & 6.7 \\
\hline Sand, 0.02-2 mm (\%) & 65.1 & 58.3 & 61.7 \\
\hline Silt, 0.002-0.2 mm (\%) & 15.6 & 14.7 & 16.9 \\
\hline Clay, <0.002 mm (\%) & 19.3 & 27.0 & 21.4 \\
\hline Organic carbon (\%) & 0.63 & 0.69 & 0.64 \\
\hline CEC (meq $100 \mathrm{~g}^{-1}$ ) & 11.13 & 10.94 & 11.67 \\
\hline Surface area $\left(\mathrm{m}^{2} \mathrm{~g}^{-1}\right)$ & 51.3 & 45.1 & 48.67 \\
\hline $\mathrm{EC}\left(\mathrm{mS} \mathrm{m}^{-1}\right)$ & 0.29 & 0.31 & 0.33 \\
\hline Specific gravity & 2.11 & 2.15 & 2.08 \\
\hline Olsen P (mg kg-1) & 9.38 & 9.16 & 10.48 \\
\hline $\mathrm{SO}_{4}\left(\mathrm{mg} \mathrm{kg}^{-1}\right)$ & 11.16 & 12.37 & 11.68 \\
\hline Acid oxalate Al\% & $0.21 \%$ & $0.22 \%$ & 0.26 \\
\hline Acid oxalate Fe\% & $0.03 \%$ & $0.06 \%$ & 0.05 \\
\hline $\mathrm{K}\left(\mathrm{cmol} \mathrm{Kg}{ }^{-1}\right)$ & 1.85 & 1.82 & 1.73 \\
\hline $\mathrm{Ca}\left(\mathrm{cmol} \mathrm{Kg}{ }^{-1}\right)$ & 3.49 & 4.45 & 3.94 \\
\hline $\mathrm{Mg}\left(\mathrm{cmol} \mathrm{Kg}^{-1}\right)$ & 1.23 & 1.21 & 1.27 \\
\hline $\mathrm{Na}\left(\mathrm{cmol} \mathrm{Kg}{ }^{-1}\right)$ & 0.11 & 0.19 & 0.17 \\
\hline
\end{tabular}

of each treatment was assayed by the Klein et al. (1971), reduction method using 2, 3, 5-Triphenyl Tetrazolium Chloride as reducing agent. From the $10 \mathrm{~g}$ of soil from each beaker 5 $\mathrm{g}$ of soil sample were mixed with $50 \mathrm{mg}$ of $\mathrm{CaCO}_{3}$ and $1 \mathrm{ml}$ of $3 \%(w / v) 2,3,5$-Triphenyltetrazolium Chloride (TTC) and again incubated for $24 \mathrm{~h}$ at $37 \pm 1{ }^{\circ} \mathrm{C}$. Dehydrogenase enzyme converts TTC to 2, 3, 5-Triphenyl Formazan (TPF). The TPF formed was extracted with acetone $(3 \times 15 \mathrm{ml})$, the extracts were filtered through Whatman Number 1 and absorption was measured at $487 \mathrm{~nm}$ with double beam spectrophotometer. Effect of metsulfuron-methyl on dehydrogenase activity was calculated relative to the control. The data obtained from this experiment were subjected to statistical analysis using SAS 9.3 version. For calculating two-way ANOVA, three different soils types and incubation time was taken as the factors. Acid phosphatase activity was assayed using $1 \mathrm{~g}$ soil (wet equivalent), $4 \mathrm{ml}$ of $0.1 \mathrm{M}$ modified universal buffer (pH 6.5), and $1 \mathrm{ml}$ of $25 \mathrm{mM}$ p-nitrophenyl phosphate. After incubation for $1 \mathrm{~h}$ at $37 \pm 1^{\circ} \mathrm{C}$ the enzyme reaction was stopped by adding $4 \mathrm{ml}$ of $0.5 \mathrm{M} \mathrm{NaOH}$ and $1 \mathrm{ml}$ of $0.5 \mathrm{M} \mathrm{CaCl}_{2}$ to prevent dispersion of humic substances. After centrifugation at $4000 \mathrm{rpm}$ for $10 \mathrm{~min}$, the absorbance was measured in the supernatant at $400 \mathrm{~nm}$; acid phosphatase activity was expressed as $\mu \mathrm{g}$ p-nitrophenol released $\mathrm{g}^{-1}$ soil $\mathrm{h}^{-1}$.

\section{Results and Discussion}

Effect of lower and higher dose of metsulfuron-methyl 
herbicide in three different soil types on their dehydrogenase activity has been presented in Table 2 . Results of this experiment indicated that there was an adverse effect of metsulfuron-methyl herbicide on dehydrogenase activity initially at both the dose. With the increase in incubation period there was change in recovery of dehydrogenase activity in all the soils and the dehydrogenase activity recovery rates varied in all the three different soil types. Slower recovery at the higher recommended dose of the herbicide was observed. The herbicide does not have the

\begin{tabular}{|c|c|c|c|c|c|c|}
\hline \multirow[t]{3}{*}{ Incubation time (Days) } & \multicolumn{6}{|c|}{ Soil order } \\
\hline & \multicolumn{2}{|c|}{ Entisol } & \multicolumn{2}{|c|}{ Mollisol } & \multicolumn{2}{|c|}{ Inceptisol } \\
\hline & LD & HD & LD & HD & LD & HD \\
\hline 0 & $1.26 \pm 0.01$ & $1.26 \pm 0.02$ & $1.17 \pm 0.04$ & $1.17 \pm 0.01$ & $1.11 \pm 0.03$ & $1.11 \pm 0.02$ \\
\hline 1 & $1.23 \pm 0.03$ & $1.25 \pm 0.01$ & $1.19 \pm 0.01$ & $1.18 \pm 0.03$ & $1.08 \pm 0.02$ & $1.13 \pm 0.01$ \\
\hline 3 & $1.19 \pm 0.01$ & $1.19 \pm 0.01$ & $1.23 \pm 0.02$ & $1.19 \pm 0.03$ & $1.13 \pm 0.02$ & $1.09 \pm 0.01$ \\
\hline 5 & $1.17 \pm 0.02$ & $1.21 \pm 0.02$ & $1.19 \pm 0.02$ & $1.25 \pm 0.02$ & $1.14 \pm 0.03$ & $1.03 \pm 0.04$ \\
\hline 7 & $1.25 \pm 0.04$ & $1.22 \pm 0.03$ & $1.16 \pm 0.03$ & $1.12 \pm 0.01$ & $1.06 \pm 0.01$ & $1.01 \pm 0.04$ \\
\hline 10 & $1.27 \pm 0.02$ & $1.23 \pm 0.01$ & $1.15 \pm 0.01$ & $1.11 \pm 0.02$ & $1.05 \pm 0.02$ & $0.99 \pm 0.03$ \\
\hline 15 & $1.25 \pm 0.03$ & $1.24 \pm 0.04$ & $1.14 \pm 0.02$ & $1.09 \pm 0.01$ & $1.03 \pm 0.04$ & $0.97 \pm 0.04$ \\
\hline \multicolumn{7}{|l|}{ For lower dose (4 g a.i.) } \\
\hline & \multicolumn{2}{|c|}{$d f$} & \multicolumn{2}{|c|}{$\mathrm{F}$} & \multicolumn{2}{|c|}{ p-level } \\
\hline Factor A (Soil) & \multicolumn{2}{|c|}{2} & \multicolumn{2}{|c|}{1009} & \multicolumn{2}{|c|}{$<0.0001$} \\
\hline Factor B (Incubation period) & \multicolumn{2}{|c|}{5} & \multicolumn{2}{|c|}{45} & \multicolumn{2}{|c|}{$<0.0001$} \\
\hline Interaction $(A \times B)$ & \multicolumn{2}{|c|}{10} & \multicolumn{2}{|c|}{37} & \multicolumn{2}{|c|}{$<0.0001$} \\
\hline \multicolumn{7}{|l|}{ For higher dose (6 g a.i.) } \\
\hline & \multicolumn{2}{|c|}{ df } & \multicolumn{2}{|c|}{$\mathrm{F}$} & \multicolumn{2}{|c|}{ p-level } \\
\hline Factor A (Soil) & \multicolumn{2}{|c|}{2} & \multicolumn{2}{|c|}{1591} & \multicolumn{2}{|c|}{$<0.0001$} \\
\hline Factor B (Incubation period) & \multicolumn{2}{|c|}{5} & \multicolumn{2}{|c|}{127} & \multicolumn{2}{|c|}{$<0.0001$} \\
\hline Interaction $(A \times B)$ & \multicolumn{2}{|c|}{10} & \multicolumn{2}{|c|}{59} & \multicolumn{2}{|c|}{$<0.0001$} \\
\hline
\end{tabular}

*LD=Lower dose ( $4 \mathrm{~g}$ a.i. $)$; HD=Higher dose ( $6 \mathrm{~g}$ a.i.); data are presented as mean $\pm S D$ of three replicates

same impact on the dehydrogenase activity for the three soil types and dehydrogenase activity depends on the incubation period as the $p$ value for factor $A$ (soil) is $<0.0001$. At a lower recommended dose of $4 \mathrm{~g}$ a.i. ha ${ }^{-1}$ the recovery rates in all the soils types was variable. In all the soils, a decrease in dehydrogenase activity was observed till the $15^{\text {th }} \mathrm{d}$ of the incubation period at higher dose. But, for entisol dehydrogen activity increased till the $15^{\text {th }}$ day only at lower dose. The initial ( 0 day) value 1.26, 1.17 and 1.11 reached to final 1.25, 1.14 and 1.03 at lower dose on $15^{\text {th }}$ day for entisol, mollisol and inceptisol, respectively. In Entisol, dehydrogenase activity decreased till $5^{\text {th }}$ day (1.17) and thereafter increased upto $15^{\text {th }}$ days (1.25). For mollisol dehydrogenase activity increased upto $3^{\text {rd }}$ day (1.23) and there after decreased. Again, for inceptisol dehydrogenase activity decreased upto $1^{\text {st }}$ day (1.08), then increased upto $5^{\text {th }}$ day (1.14) and thereby decreased upto 15 day (1.03). A better response of the activity to the lower dose was observed in all the soils. This indicating that dose of the herbicides may changes the toxicity in the soils. Higher dose adversely affect soil dehydrogenase activity more as compare to lower dose. Besides soil varying soil order also contributed wide difference in dehydrogenase activity which may be due to difference in physico-chemicals properties of the soil order. Maarit Niemi et al. (2009) showed that stimulation or decreased depended on the enzyme, the herbicide, its concentration and duration of the exposure. Also, Dutta et al. (2010) studied the effects of chlorpyrifos on the Fluorescein Diacetate Hydrolysing Activity (FDA) and showed that this enzyme activity was not affected by chlorpyrifos at field rate, but at higher dosage significantly decreased was observed.

At a higher dose of $6 \mathrm{~g}$ a.i. ha ${ }^{-1}$, the dehydrogenase activity recovery rate in all the soils types was slow. The initial (0 day) value $1.26,1.17$ and 1.11 reached to final $1.24,1.09$ and 0.97 at higher dose on $15^{\text {th }}$ day for entisol, mollisol and inceptisol, respectively. Likewise, in a study conducted by Fang et al. (2009) an increase in the inhibitory effect of chlorpyrifos on soil microbes with increasing pesticide concentrations was 
observed. In Entisol dehydrogenase activity decreased upto $3^{\text {rd }}$ day (1.19) and thereafter increased upto $15^{\text {th }}$ day (1.24). In Mollisol dehydrogenase activity increased upto $5^{\text {th }}$ days (1.25) and thereafter decreased upto $15^{\text {th }}$ day (1.09). But in Inceptisol slightly different trends was observed. In Inceptisol, dehydrogenase activity increased at $1^{\text {st }}$ day (1.13) and then decreased slowly upto $15^{\text {th }}$ days (0.97). At higher dose the pattern of changes of dehydrogen activity with time changes significantly and this is only due to varying in physicochemical properties of different soil. Similar report has been suggested by Mukherjee et al. (2016) in case of flubendiamide.

In case of acid phosphatase, initial acid phosphate value $1.30,1.28$ and 1.31 reached to final $1.26,1.28$ and 1.26 at lower dose respectively for entisol, mollisol and inceptisol. In all the three soil type, a decrease in acid phosphatase activity was observed till the $15^{\text {th }} \mathrm{d}$ of the incubation period. But for mollisol at lower dose there was no change in acid phosphatase activity. Slower recovery at the higher dose of the herbicide was observed. At lower dose ( $4 \mathrm{~g}$ a.i. ha ${ }^{-1}$ ) the recovery rates in all the soils types was also variable. In entisol acid phosphatase activity increased upto $3^{\text {rd }}$ day (1.32) and there after decrease upto $15^{\text {th }}$ day (1.26). But, in case of mollisol acid phosphatase activity decreased up to $5^{\text {th }}$ day (1.24) and thereafter increased up to $15^{\text {th }}$ day (1.28). For inceptisol acid phosphatase activity increased up to $3^{\text {rd }}$ day (1.31) and there after decreased continuously up to $15^{\text {th }}$ day. Similar trend has also been observed by Das et al. (2015).

Initial acid phosphate value 1.30, 1.28 and 1.31 reached to final 1.26, 1.22 and 1.25 at higher dose, respectively for entisol, mollisol and inceptisol. At higher dose (6 g a.i. ha-1), for entisol, acid phosphatase activity increased up to $3^{\text {rd }}$ day (1.35) and thereafter decreased up to $15^{\text {th }}$ day (1.26). But, for mollisol acid phosphatase activity decreased up to $3^{\text {rd }}$ day (1.25), then on $5^{\text {th }}(1.26)$ day increased and again decreased from $7^{\text {th }}$ day (1.24) to $15^{\text {th }}$ day (1.22). Similarly for inceptisol acid phosphatase activity decrease up to $3^{\text {rd }}$ day (1.30) then increase in $5^{\text {th }}$ day (1.31) and again decrease from $5^{\text {th }}$ day (1.31) up to $15^{\text {th }}$ day (1.25). Similar observations were also made by Pandey and Singh (2004); Singh and Singh (2005a, b); Tejada et al. (2011) who reported that dehydrogenase activities were inhibited by insecticides. Inhibition of dehydrogenase activity by chlorpyrifos and quinalphos was also reported by Menon et al. (2005). In the other hand some studies showed dehydrogenase activity increasing after pesticides application (Fragoeiro and Magan, 2008; Singh and Kumar, 2008) (Table 3).

This study shows that significant difference in enzymatic activity in three different soil order i.e. entisol, mollisol and inceptisol is due to variation in physico-chemical properties

Table 3: Effect of lower and higher dose metsulfuron-methyl in three different soil types on their acid phosphatase activity (in logarithm of soil phosphatase activity)

\begin{tabular}{|c|c|c|c|c|c|c|}
\hline \multirow[t]{3}{*}{ Incubation time (Days) } & \multicolumn{6}{|c|}{ Soil order } \\
\hline & \multicolumn{2}{|c|}{ Entisol } & \multicolumn{2}{|c|}{ Mollisol } & \multicolumn{2}{|c|}{ Inceptisol } \\
\hline & LD & HD & LD & $\mathrm{HD}$ & LD & $\mathrm{HD}$ \\
\hline 0 & $1.30 \pm 0.02$ & $1.30 \pm 0.01$ & $1.28 \pm 0.02$ & $1.28 \pm 0.03$ & $1.31 \pm 0.03$ & $1.31 \pm 0.03$ \\
\hline 1 & $1.31 \pm 0.01$ & $1.32 \pm 0.03$ & $1.27 \pm 0.03$ & $1.26 \pm 0.01$ & $1.30 \pm 0.02$ & $1.30 \pm 0.01$ \\
\hline 3 & $1.32 \pm 0.01$ & $1.35 \pm 0.03$ & $1.25 \pm 0.02$ & $1.25 \pm 0.01$ & $1.31 \pm 0.01$ & $1.30 \pm 0.02$ \\
\hline 5 & $1.29 \pm 0.02$ & $1.31 \pm 0.03$ & $1.24 \pm 0.01$ & $1.26 \pm 0.02$ & $1.29 \pm 0.04$ & $1.31 \pm 0.03$ \\
\hline 7 & $1.27 \pm 0.3$ & $1.28 \pm 0.02$ & $1.26 \pm 0.03$ & $1.24 \pm 0.02$ & $1.27 \pm 0.01$ & $1.27 \pm 0.04$ \\
\hline 10 & $1.26 \pm 0.4$ & $1.28 \pm 0.01$ & $1.27 \pm 0.04$ & $1.23 \pm 0.03$ & $1.28 \pm 0.03$ & $1.26 \pm 0.02$ \\
\hline 15 & $1.26 \pm 0.2$ & $1.26 \pm 0.02$ & $1.28 \pm 0.03$ & $1.22 \pm 0.01$ & $1.26 \pm 0.02$ & $1.25 \pm 0.04$ \\
\hline \multicolumn{7}{|l|}{ For lower dose (4 g a.i.) } \\
\hline & \multicolumn{2}{|c|}{$d f$} & \multicolumn{2}{|c|}{$\mathrm{F}$} & \multicolumn{2}{|c|}{$p$-level } \\
\hline Factor A (Soil) & \multicolumn{2}{|c|}{2} & \multicolumn{2}{|c|}{1246} & \multicolumn{2}{|c|}{$<0.0001$} \\
\hline Factor B (Incubation period) & \multicolumn{2}{|c|}{5} & \multicolumn{2}{|c|}{61} & \multicolumn{2}{|c|}{$<0.0001$} \\
\hline Interaction $(\mathrm{A} \times \mathrm{B})$ & \multicolumn{2}{|c|}{10} & \multicolumn{2}{|c|}{37} & \multicolumn{2}{|c|}{$<0.0001$} \\
\hline \multicolumn{7}{|l|}{ For higher dose (6 g a.i.) } \\
\hline & \multicolumn{2}{|c|}{$d f$} & \multicolumn{2}{|c|}{$\mathrm{F}$} & \multicolumn{2}{|c|}{$p$-level } \\
\hline Factor A (Soil) & \multicolumn{2}{|c|}{2} & \multicolumn{2}{|c|}{1579} & \multicolumn{2}{|c|}{$<0.0001$} \\
\hline Factor B (Incubation period) & \multicolumn{2}{|c|}{5} & \multicolumn{2}{|c|}{76} & \multicolumn{2}{|c|}{$<0.0001$} \\
\hline Interaction $(\mathrm{A} \times \mathrm{B})$ & \multicolumn{2}{|c|}{10} & \multicolumn{2}{|c|}{43} & \multicolumn{2}{|c|}{$<0.0001$} \\
\hline
\end{tabular}

*LD=Lower dose (4 g a.i.); HD=Higher dose (6 $\mathrm{g}$ a.i.); data are presented as mean \pm SD of three replicates 
as well as the differences in potential microbes which plays a significant role.

\section{Conclusion}

The herbicide metsulfuron methyl exhibits different behavior under different soil type due to varying in physicochemical properties of the soil order. These leads to changes in both the enzyme viz., dehydrogenase and phosphatase activity in all the soil type. At lower dose enzymes were less affected than higher dose due to toxic effect at higher dose. The herbicide affected more for both the enzyme in inceptisol than mollisol and entisol at both doses.

\section{References}

Black, C.A., 1965. Method of Soil Analysis (parts 1 and 2). American Society of Agronomy, Madison, WI.

Blakemore, L.C., Searle, P.L., Daly, B.K., 1987. Methods for Chemical Analysis of Soils. New Zealand Soil Bureau Scientific Report.

Bouyoucos, G.J., Cook, R.L., 1967. Measuring the relative humidity of soils at different moisture contents by the gray hydrocal hygrometer. Soil Science 104, 297-305.

Das, S.K., Mukherjee, I., 2011. Effect of light and pH on persistence of flubendiamide. Bulletin of Environmental Contamination and Toxicology 87, 292-296.

Das, S.K., Mukherjee, I., 2012. Effect of moisture and organic manure on persistence of flubendiamide in soil. Bulletin of Environmental Contamination and Toxicology 88, 515-520.

Das, S.K., Mukherjee, I., Das, S.K., 2012. Dissipation of flubendiamide in/on Okra [Abelmoschus esculenta (L.) Moench] Fruits. Bulletin of Environmental Contamination and Toxicology 88, 381-384.

Das, S.K., Mukherjee, I., 2014. Influence of microbial community on degradation of flubendiamide in two Indian soils. Environmental Monitoring and Assessment 186, 3213-3219.

Das, S.K., Mukherjee, I., Kumar, A., 2015. Effect of soil type and organic manure on adsorption-desorption of flubendiamide. Environmental Monitoring and Assessment 187, 403. DOI 10.1007/s10661-015-4623-2.

Dutta, M., Sardar, D., Pal, R., Kole, R.K., 2010. Effect of chlorpyrifos on microbial biomass and activities in tropical clay loam soil. Environmental Monitoring and Assessment 160, 385-391.

Menon, P., Gopal, M., Parsad, R., 2005. Effects of chlorpyrifos and quinalphos on dehydrogenase activities and reduction of $\mathrm{Fe}_{3}+$ in the soils of two semi-arid fields of tropical India. Agriculture Ecosystem and Environment 108, 73-83.

Mukherjee, I., Das, S.K., Kumar, A., 2016. Degradation of flubendiamide as affected by elevated $\mathrm{CO}_{2}$, temperature and carbon mineralization rate in soil. Environmental Science and Pollution Research DOI 10.1007/s11356016-7145-8.
Dinesh, R., Dubey, R.P., Ganeshamurthy, A.N., Prasad, S.G., 2000. Organic manuring in rice-based cropping system: Effects on soil microbial biomass and selected enzyme activities. Current Science 79, 1716-1720.

Fang, H., Yunlong, Y.U., Xiaoqiang, C.H.U., Xiuguo, W., Xiaoe, Y., Jingquan, Y.U., 2009. Degradation of chlorpyrifos in laboratory soil and its impact on soil microbial functional diversity. Journal of Environmental Science 21, 380-386.

Floch, C., Chevremont, A.C., Joanico, K., Capowiez, Y., Criquet, S., 2011. Indicators of pesticide contamination: soil enzyme compared to functional diversity of bacterial communities via Biolog Ecoplates. European Journal Soil Biology 47, 256-263.

Fragoeiro, S., Magan, N., 2008. Impact of trametes versicolor and phanerochaete chrysosporium on differential breakdown of pesticide mixtures in soil microcosms at two water potentials and associated respiration and enzyme activity. International Bio-deterioration and Bio-degradation 62, 376-383.

Goyal, S., Mishra, M.M., Dhankar, S.S., Kapoor, K.K., Batra, R., 1993. Microbial biomass turnover and enzyme activities following the application of farmyard manure to field soils with and without previous long-term applications. Biology and Fertility of Soils 15, 60-64.

Hussain, S., Siddique, T., Saleem, M., Arshad, M., Khalid, A., 2009. Impact of pesticides on soil microbial diversity, enzymes, and biochemical reactions. Advance in Agronomy 102, 159-200.

Jackson, M.L., 1967. Soil chemical analysis. Prentice Hall, New Delhi, India.

Jastrzebska, E., 2011. The effect of chlorpyrifos and teflubenzuron on the enzymatic activity of soil. Polish Journal Environmental Studies 20, 903-910.

Klein, D.A, Loh, T.C., Goulding, R.L., 1971. A rapid procedure to evaluate dehydrogenase activity of soils low in organic matter. Soil Biology and Biochemistry 3, 385-387.

Klose, S.A., Martina, V., Ajwa, H.A., 2006. Microbial community composition and enzyme activities in a sandy loam soil after fumigation with methyl bromide an alternative soil biocide. Soil Biology and Biochemistry 38, 1243-1254.

Maarit, N., Heiskanen, R.I., Ahtiainen, J.H., Rahkonen, A., Mantykoski, K., Welling, L., Laitinen, L., Ruuttunen, P., 2009. Microbial toxicity and impacts on soil enzyme activities of pesticides used in potato cultivation. Applied Soil Ecology 41, 293-304.

Pandey, S., Singh, D.K., 2004. Total bacterial and fungal population after chlorpyrifos and quinalphos treatments in groundnut (Arachis hypogaea L.) soil. Chemospher 55, 197-205.

Sebiomo, A., Ogundero, V.W., Bankole, S.A., 2012. Effect of four herbicides on microbial population, soil organic matter and dehydrogenase activity. African Journal Biotechnology 10, 770-778.

Singh, D.K., Kumar, S., 2008. Niroreductase, arginine 
deaminase, urease and DHA in natural soil (ridges with forest) and in cotton soil after acetamoprid treatment. Chemosphere 71, 412-418.

Singh, D.K., Kumar, S., 2008. Nitrate reductase, arginine deaminase, urease and dehydrogenase activities in natural soil (ridges with forest) and in cotton soil after acetamiprid treatments. Chemosphere 71, 412-418.

Singh, J., Singh, D.K., 2005a. Available nitrogen and arginine deaminase activity in groundnut (Arachis hypogaea L.) field after diazinon, imidacloprid and lindane treatments. Journal of Agriculture and Food Chemistry 53, 363-368.

Singh, J., Singh, D.K., 2005b. Dehydrogenase and phosphomonoesterase activities in groundnut (Arachis hypogaea L.) field after diazinon, imidacloprid and lindane treatments. Chemosphere 60, 32-42.
Sukul, 2006. Enzymatic activities and microbial biomass in soil as influenced by metalaxyl residues. Soil Biology and Biochemistry, 38, 320-326.

Tejada, M., Gomez, I., Del Toro, M., 2011. Use of organic amendments as a bioremediation strategy to reduce the bio-availability of chlorpyrifos insecticide in soils. Effects on Soil Biology. Ecotoxicology and Environmental Safety 74, 2075-2081.

Walkley Black, C.A., 1965. Organic Carbon: Methods of soil analysis (parts 1 and 2). Agronomy 9, 1367-1378. American. Society of Agronomy, Inc., Madison, WI.

Xia, XM., Zhao, M., Wang, H.Y., Ma, H., 2011. Influence of butachlor on soil enzymes and Microbial growth. Journal of Food, Agriculture and Environment 9, 753-756. 